\title{
Characterization and identification of Au pathfinder minerals from an artisanal mine site using X-ray diffraction
}

\author{
Gabriel Nzulu ${ }^{1}$, Per Eklund ${ }^{1}$ (D), and Martin Magnuson ${ }^{1, \star}$ (D) \\ ${ }^{1}$ Department of Physics, Chemistry and Biology, IFM, Thin Film Physics Division, Linköping University, Linköping, Sweden
}

Received: 20 November 2020

Accepted: 11 December 2020

Published online:

11 January 2021

(C) The Author(s) 2021

\begin{abstract}
Gold-associated pathfinder minerals have been investigated by identifying host minerals of $\mathrm{Au}$ for samples collected from an artisanal mining site near a potential gold mine (Kubi Gold Project) in Dunkwa-On-Offin in the central region of Ghana. We find that for each composition of Au powder (impure) and the residual black hematite/magnetite sand that remains after gold panning, there is a unique set of associated diverse indicator minerals. These indicator minerals are identified as $\mathrm{SiO}_{2}$ (quartz), $\mathrm{Fe}_{3} \mathrm{O}_{4}$ (magnetite) and $\mathrm{Fe}_{2} \mathrm{O}_{3}$ (hematite), while contributions from pyrite, arsenopyrites, iridosmine, scheelite, tetradymite, garnet, gypsum and other sulfate materials are insignificant. This constitutes a confirmative identification of $\mathrm{Au}$ pathfinding minerals in this particular mineralogical area. The findings suggest that X-ray diffraction could also be applied in other mineralogical sites to aid in identifying indicator minerals of $\mathrm{Au}$ and the location of ore bodies at reduced environmental and exploration costs.
\end{abstract}

\section{Introduction}

At mineralogical mining sites, the fast location of ore bodies is paramounted in order to reduce exploration costs. For this purpose, pathfinding minerals are important. These minerals act as an aid in the original ore body discovery. Au that can be traced from the presence of pathfinding minerals mostly originates as anhedral crystal assemblies (i.e., without well-defined crystal facets) that naturally exist as single or polycrystalline mineral aggregates that are usually found in situ in hydrothermal quartz veins and other kinds of key deposits in metamorphic and igneous rocks $[1,2]$.

The most common mineral at most Au mining sites is pyrite $\left(\mathrm{FeS}_{2}\right)$ that can also be found in oil shales and coal [3]. Other common minerals at Au mining sites are arsenopyrite, different forms of silicate minerals (garnet) and magnetite $\left(\mathrm{Fe}_{3} \mathrm{O}_{4}\right)$. Both mineralogical and geochemical information are indispensable to

Handling Editor: M. Grant Norton.

Address correspondence to E-mail: martin.magnuson@liu.se 
provide an initial valuation of the potential ore zone of an exploration area.

Quantitative interpretation of X-ray diffraction (XRD) data [4] has long been applied to distinguish between mineral assemblages, and to define chemical and mineralogical compositions [5]. Previous XRD studies of $\mathrm{Au}$ and associated minerals have mostly been performed to determine the grain size morphology and crystallinity [6]. XRD has been used to conclude that highly hydrated and water-saturated environments contribute to the migration of $\mathrm{Au}$ within alluvial regimes and on hydrothermal mineral assemblages [7-9]. Multivariate statistical analysis and geostatistical methods have been applied to identify pathfinding elements [10, 11]. Bayari et al. [4] found that mineralized regolith profiles and mobility of elements (minerals) in the soil at the Bole-Nangoli gold belt in the north-eastern Ghana could mainly be attributed to amorphous mineral phases. Furthermore, Zhao and Pring (2019) [12] studied the mineral transformation in $\mathrm{Au}$ and silver $(\mathrm{Ag})$ in fluids using the telluride group of minerals associated with $\mathrm{Au}$ and focused on the texture, reaction mechanism and the kinetics of the oxidation leaching of the tellurides.

Cairns et al. [13] identified topsoil minerals and pathfinders of $\mathrm{Au}$ by considering the fine grain size and amorphous nature of the minerals. Furthermore, XRD studies on the influence of thermal stability of magnetite investigate the effect of temperature on the phase transitions [14-21]. This information is of importance for the investigation of magnetite as a pathfinder mineral of $\mathrm{Au}$. As follows from this background, there is still a need for the characterization of pathfinding Au-associated minerals by XRD on residual samples to establish their relationship and to preserve information about the physiochemical situations of their origin.

In this work, we investigate the crystal structure of $\mathrm{Au}$ in relation to the corresponding pathfinding minerals, such as quartz $\left(\mathrm{SiO}_{2}\right), \mathrm{Fe}_{3} \mathrm{O}_{4}, \mathrm{Fe}_{2} \mathrm{O}_{3}, \mathrm{FeS}_{2}$ and $\mathrm{Fe}_{1-\mathrm{x}} \mathrm{S}$, collected from an artisanal mining site, i.e., a small-scale hand-mining site, in the central region of Ghana. XRD was used for phase identification and to obtain structural information including Rietveld refinement. In addition to the known minerals, we also identified hematite $\left(\mathrm{Fe}_{2} \mathrm{O}_{3}\right)$ as an important pathfinding mineral. The present study can be used to enable future identification of pathfinding minerals for Au exploration.

\section{Experimental details}

\section{Description of the field site}

The sample collection site is located close to the Kubi Gold (Adansi Gold) on the outskirt of Dunkwa-OnOffin, (5 $58^{\prime \prime} 11.32^{\prime \prime} \mathrm{N}, 1^{\circ} 46^{\prime} 59.15^{\prime \prime} \mathrm{W}$ ) as shown in Fig. 1. Dunkwa is the capital of the Upper Denkyira East Municipal District located in the central region of Ghana and is drained by several rivers and streams with the Offin river serving as the main river source. The location follows the geology of Ghana which is associated with the antiquity of crystalline basement rock, volcanic belts and sedimentary basins. Most $\mathrm{Au}$ is found in steeply dipping quartz veins in shear zones within the Birimian basins with sulfur-rich minerals, such as arsenopyrites and $\mathrm{FeS}_{2}$. Other sources of $\mathrm{Au}$ found are alluvial placer $\mathrm{Au}$ in the Offin river deposits in gravels as well as some mineralized placer $\mathrm{Au}$ reconstituted with minerals, such as $\mathrm{Fe}_{3} \mathrm{O}_{4}$ and $\mathrm{Fe}_{2} \mathrm{O}_{3}$ in quartz-pebble conglomerates of the Tarkwaian deposits [22]. Extremely oxidized, weathered or putrefied rock commonly located at the upper and exposed part of the ore deposit or mineralized vein known as "gossan" or iron cap serves as a guide to trace buried $\mathrm{Au}$ ore deposits in this area [23]. The surface oxides of the minerals at this site are usually red, orange to yellowish-brown color serving as an alteration to the parent rock or soil.

\section{Sample preparation}

Sediment samples that contain $\mathrm{Au}$ were extracted from a depth of $10 \mathrm{~m}$ of an artisanal mining site in Dunkwa-On-Offin. Figure 2 shows the depth profile at the mining site. Each sample was divided into two parts where one portion was refined into pure solid $\mathrm{Au}$, while the other part of the powder sample was subjected to Au panning, that is, washing and magnetic extraction of Fe-based minerals as shown in Fig. 2. The final three samples (Fig. 3) containing a solid Au nugget, untreated (impure) Au powder and the separated black sand-like minerals were examined by X-ray diffraction. The size of the two powder crystal samples ranges from $0.05 \mathrm{~cm}$ to about $0.2 \mathrm{~cm}$ in the maximum dimension of which most were hoppered single crystals with an octahedral crystal structure with a few being of non-octahedral forms. 


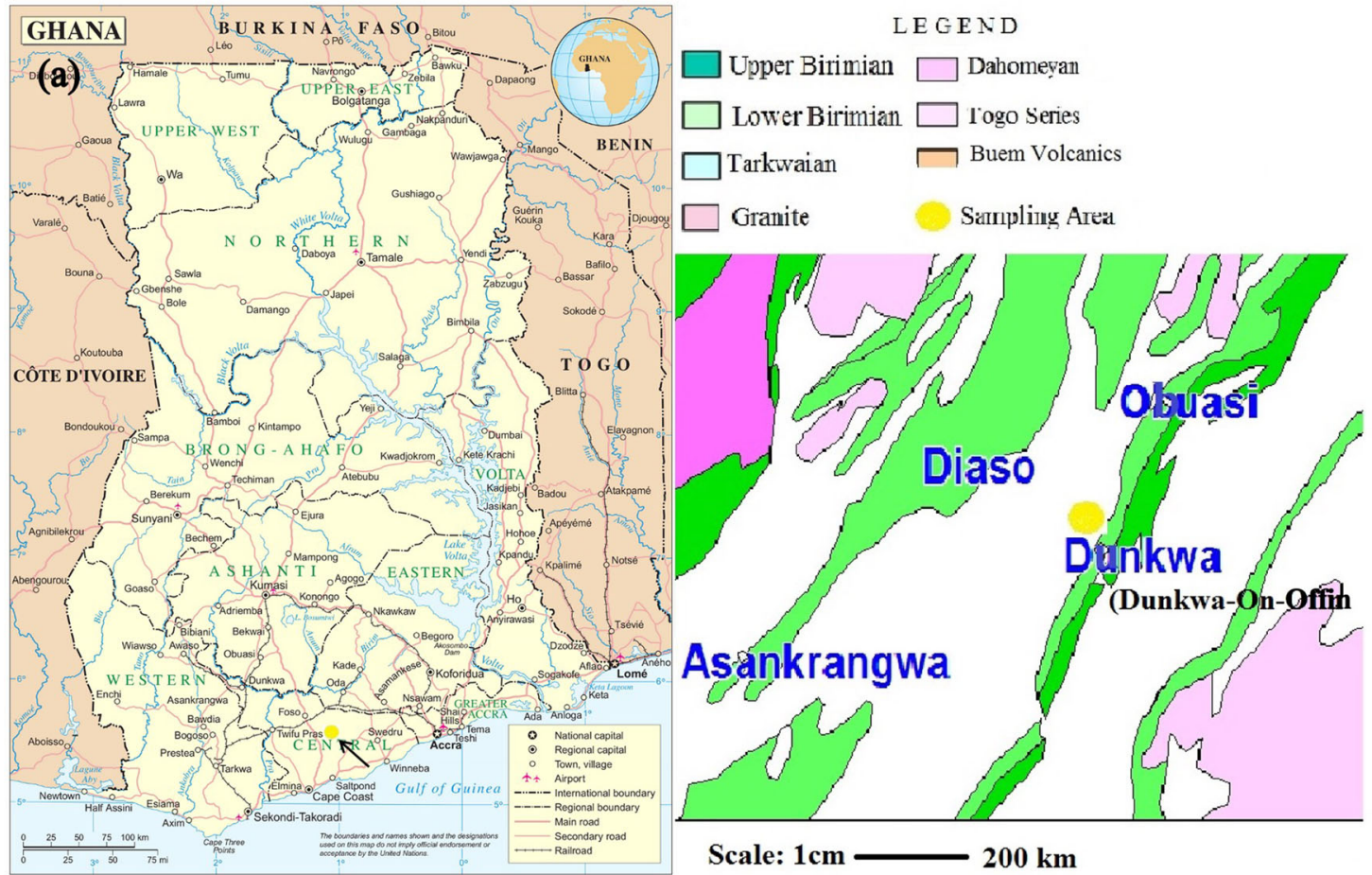

(b)

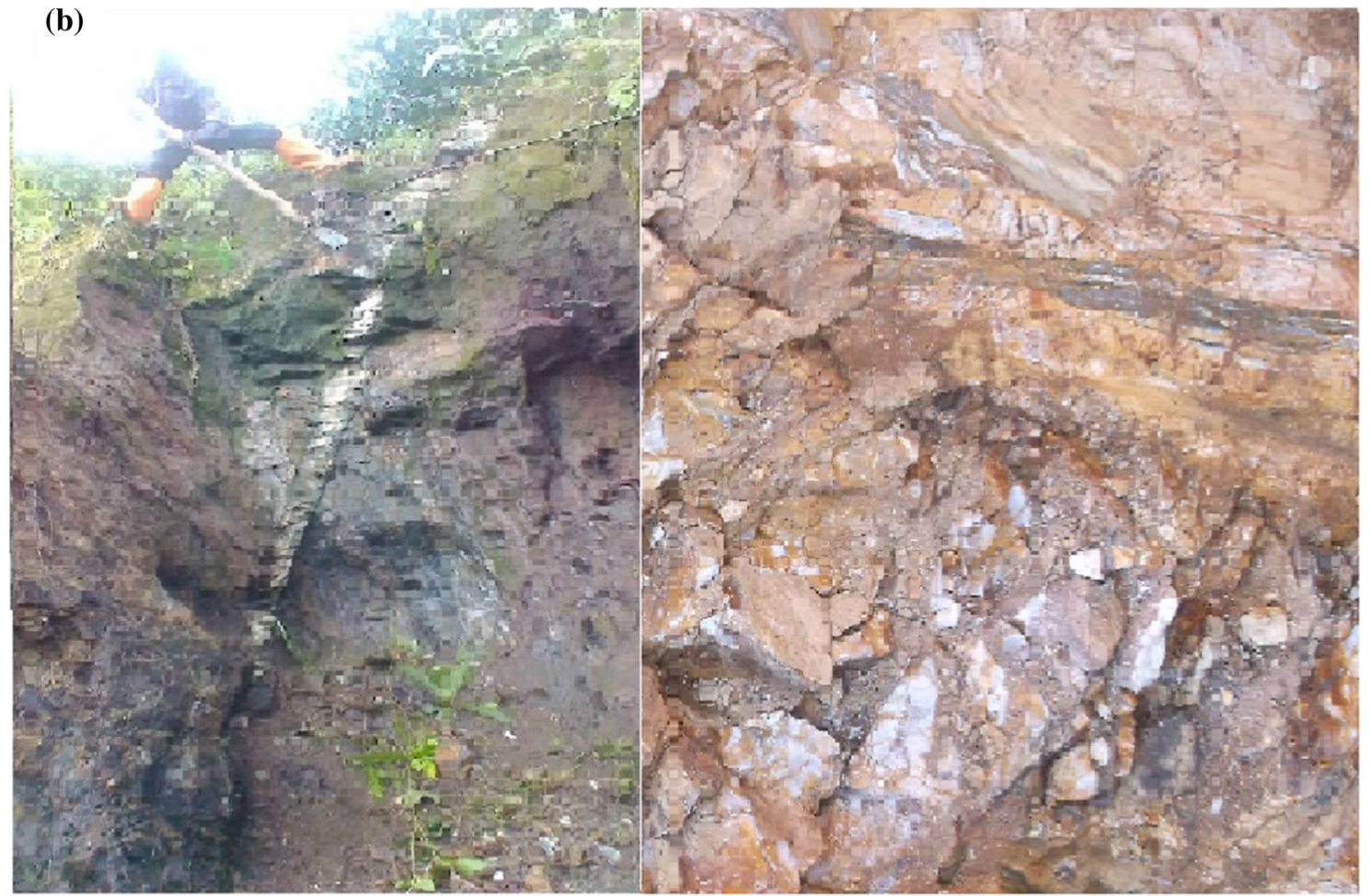

Figure 1 a Geographical and geological maps of the mining areas in and around Dunkwa-On-Offin, in the Ashanti Gold Belt of central Ghana, CC-BY license [24]. The right map indicates different rock types in four pronounced mining zones. $\mathbf{b}$ Photograph of sampling collection area of the artisanal mining site. On-site photographs by G. Nzulu in Nov. 2019. 
Figure 2 a Wet residual sample from the Dunkwa-OnOffin artisanal mine site.

b Refined part of a sample into a Au nugget of 22 carats as measured with a digital electronic Au purity Analyzer DH $300 \mathrm{~K}$ from VTSYIQI.

c Dried sample after coarse rinsing before fine panning. Note that the sample contains white quartz as well as black magnetite and hematite.

d Final impure Au after fine panning. Photographs by G. Nzulu.
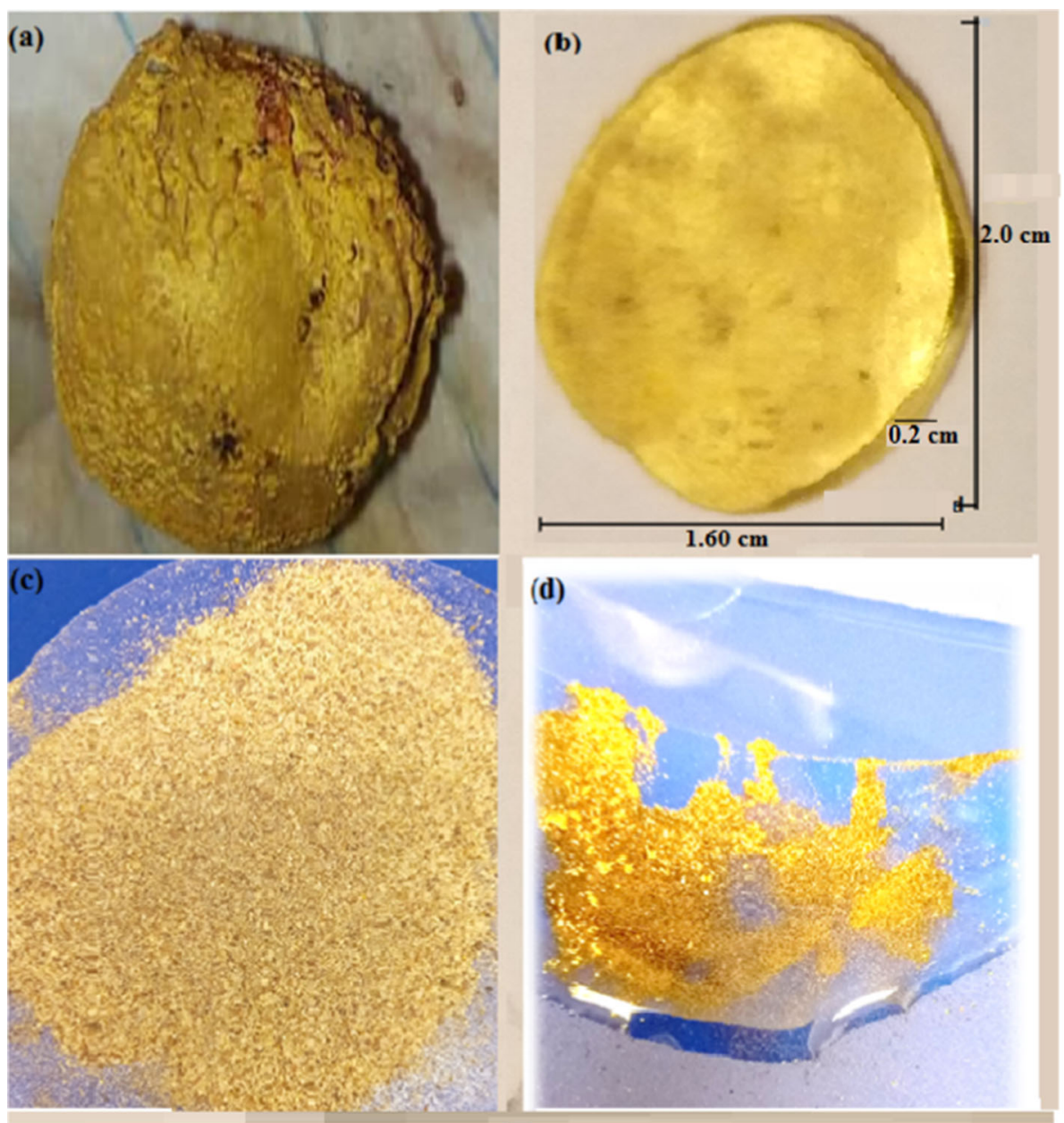

\section{Magnetizing process}

During the panning process, the black sand that consists of $\mathrm{Fe}_{3} \mathrm{O}_{4}$ (magnetite) and $\mathrm{Fe}_{2} \mathrm{O}_{3}$ (hematite) sink to the bottom of the pan. While the black sand remained in the pan, a strong permanent magnet was swept over (to and fro) in a circular motion, a couple of centimeters above the material to maximize the magnetic susceptibility (induced ferromagnetics in the $\mathrm{Fe}_{2} \mathrm{O}_{3}$ ) for easy capture of the magnetite and
Figure 3 a Final residual sample containing $\mathrm{Au}$, sand, and other magnetic materials to undergo magnetic separation. b Impure $\mathrm{Fe}_{2} \mathrm{O}_{3} /$ $\mathrm{Fe}_{3} \mathrm{O}_{4}$ minerals. Photographs by G. Nzulu.
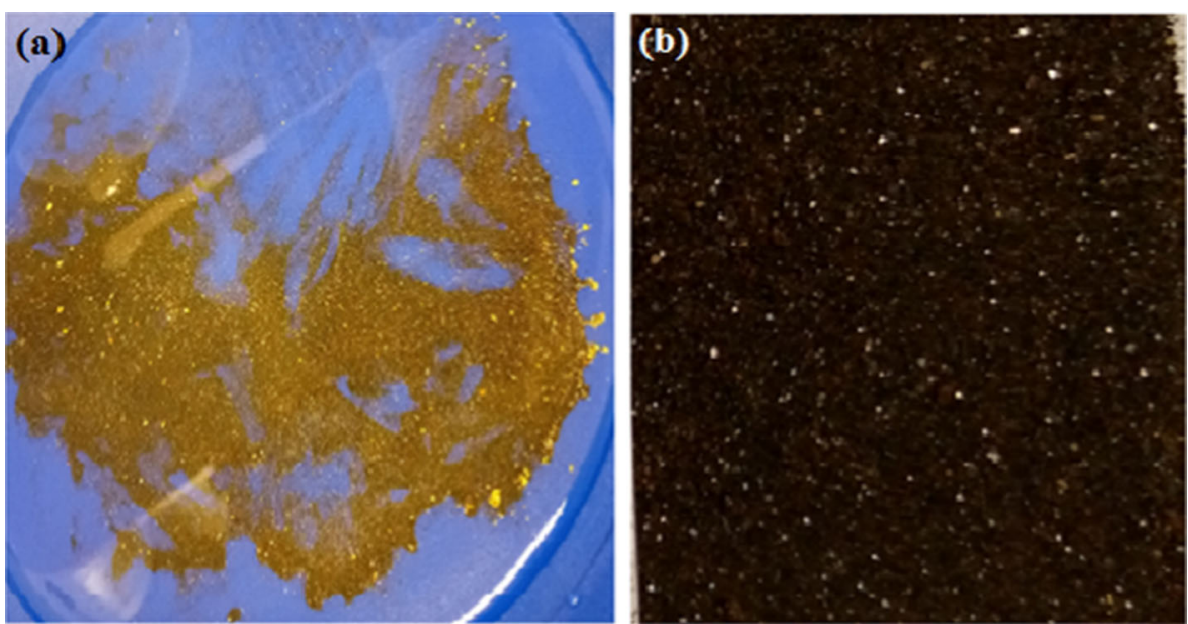
Figure 4 X-ray diffractogram of the bulk solid Au sample showing distinct peaks.

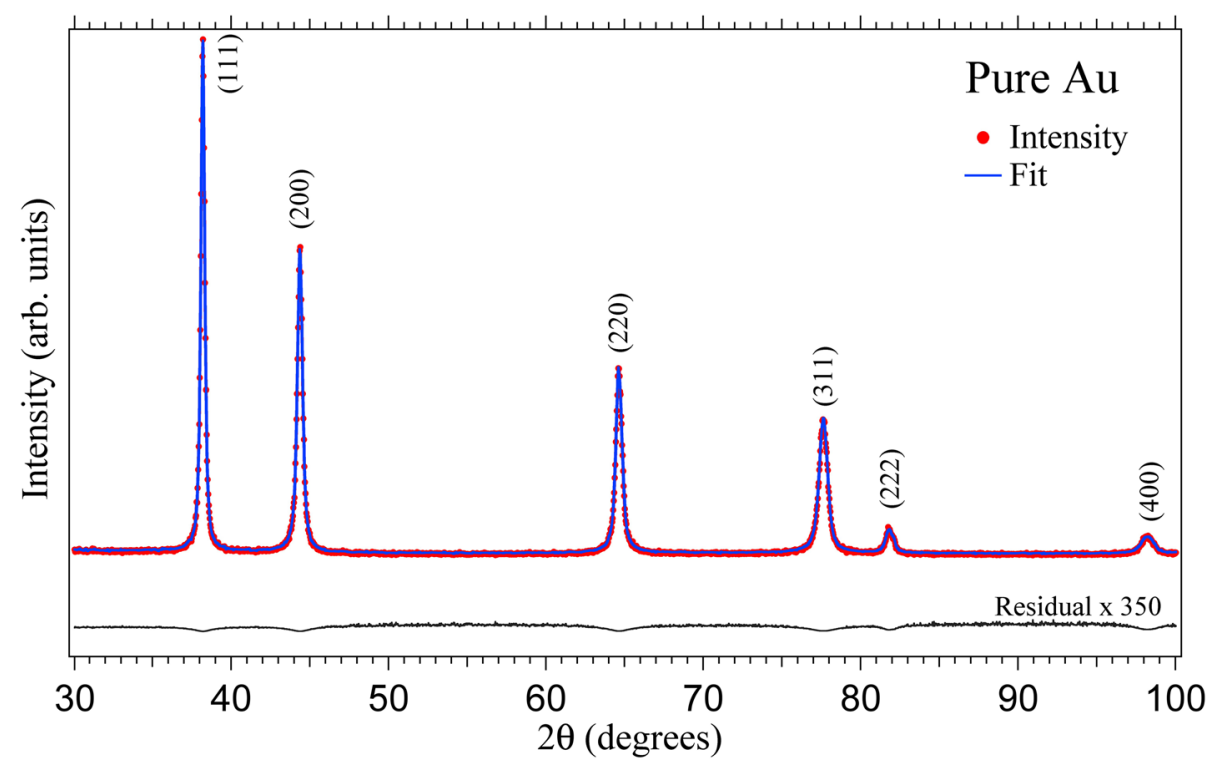

Table 1 Structural refinement parameters of solid bulk $\mathrm{Au}$ from XRD

\begin{tabular}{|c|c|c|c|c|c|c|}
\hline \multirow{2}{*}{\multicolumn{3}{|c|}{$\begin{array}{l}\text { Symmetry: cubic } \\
\text { Wavelength } \mathrm{Cu} \mathrm{K} \alpha=1.5406 \dot{\mathrm{A}}\end{array}$}} & \multicolumn{4}{|c|}{ Space group $=\mathrm{Fm}-3 \mathrm{~m}$} \\
\hline & & & \multirow{2}{*}{\multicolumn{2}{|c|}{ COD ID: 9008463}} & \multirow{2}{*}{\multicolumn{2}{|c|}{$\begin{array}{l}\text { Ref. cell volume }=67.83 \AA^{3} \\
\text { Refined cell volume }=67.82 \AA^{3}\end{array}$}} \\
\hline \multicolumn{3}{|c|}{ Wavelength $\mathrm{Cu} \mathrm{K} \beta=1.5444 \dot{\mathrm{A}}$} & & & & \\
\hline \multicolumn{3}{|l|}{ Observed } & \multicolumn{2}{|c|}{ Calculated } & \multicolumn{2}{|c|}{ Difference } \\
\hline 2 theta & $\mathrm{d}$ & h k 1 & 2 theta & $\mathrm{d}$ & 2 theta & $\mathrm{d}$ \\
\hline 38.211 & 2.35344 & 111 & 38.185 & 2.35500 & 0.026 & 0.00156 \\
\hline 44.394 & 2.03895 & 200 & 44.393 & 2.03900 & 0.001 & -0.00005 \\
\hline 64.615 & 1.40276 & 220 & 64.578 & 1.44200 & 0.037 & -0.03924 \\
\hline 77.616 & 1.22911 & 311 & 77.549 & 1.23000 & 0.067 & -0.00089 \\
\hline 81.761 & 1.17696 & 222 & 81.724 & 1.17740 & 0.037 & -0.00044 \\
\hline 98.238 & 1.01882 & 400 & 98.137 & 1.01960 & 0.101 & -0.00078 \\
\hline \multicolumn{7}{|l|}{ Cell } \\
\hline Parameters & \multicolumn{2}{|c|}{ Refinement } & \multicolumn{2}{|c|}{ Reference } & \multicolumn{2}{|l|}{ Error } \\
\hline $\mathrm{a}(\AA)$ & \multicolumn{2}{|c|}{$4.07803 \pm 5.7603 \mathrm{E}-5$} & \multicolumn{2}{|c|}{4.07825} & \multicolumn{2}{|c|}{-0.00022} \\
\hline $\mathrm{b}(\AA)$ & \multicolumn{2}{|c|}{$4.07803 \pm 5.7603 \mathrm{E}-5$} & \multicolumn{2}{|l|}{4.07825} & \multicolumn{2}{|c|}{-0.00022} \\
\hline $\mathrm{c}(\AA)$ & \multicolumn{2}{|c|}{$4.07803 \pm 5.7603 \mathrm{E}-5$} & 4.07825 & & \multicolumn{2}{|c|}{-0.00022} \\
\hline Alpha $\left(^{\circ}\right)$ & \multicolumn{2}{|l|}{90.0000} & \multicolumn{4}{|l|}{90.0000} \\
\hline Beta $\left(^{\circ}\right)$ & \multicolumn{2}{|l|}{90.0000} & \multicolumn{4}{|l|}{90.0000} \\
\hline Gamma $\left(^{\circ}\right)$ & \multicolumn{2}{|l|}{90.0000} & \multicolumn{4}{|l|}{90.0000} \\
\hline
\end{tabular}

hematite. The process was repeated until there was no more added material on the surface of the permanent magnet. The magnetically captured material was dominated by magnetite that is a pathfinding mineral (Fig. 3b) in addition to minority minerals that can be identified using XRD.

\section{X-ray diffraction measurement}

The samples (both solid and powder forms) were irradiated using a PANAnalyical X'pert [25] powder diffractometer with a theta-2 theta configuration. The operating conditions and equipment settings were $\mathrm{Cu}-\mathrm{K} \alpha$ radiation wavelength of $1.5406 \AA \quad(\approx$ $8.04 \mathrm{keV}) ; \mathrm{Cu}$ long fine focus tube set to $45 \mathrm{kV}$ and $40 \mathrm{~mA}$; scan step size of 0.033 ; counting time of $10.16 \mathrm{~s}$ per step and scan range between 30 and $100^{\circ}$ in 2 theta scans. The size of the solid bulk Au nugget was $2 \times 1.6 \times 0.5 \mathrm{~cm}$. The powder samples of impure $\mathrm{Au}, \mathrm{Fe}_{2} \mathrm{O}_{3}$ and $\mathrm{Fe}_{3} \mathrm{O}_{4}$ had varying grain sizes $(0.05-0.2 \mathrm{~cm})$ and were put on a sample holder mounted on the diffractometer's sample mounting stage such that the crystal face was properly oriented and closely aligned with the diffractometer circle of 
Figure 5 X-ray diffractogram of the impure powder Au with other pathfinding $\mathrm{Au}$ minerals.

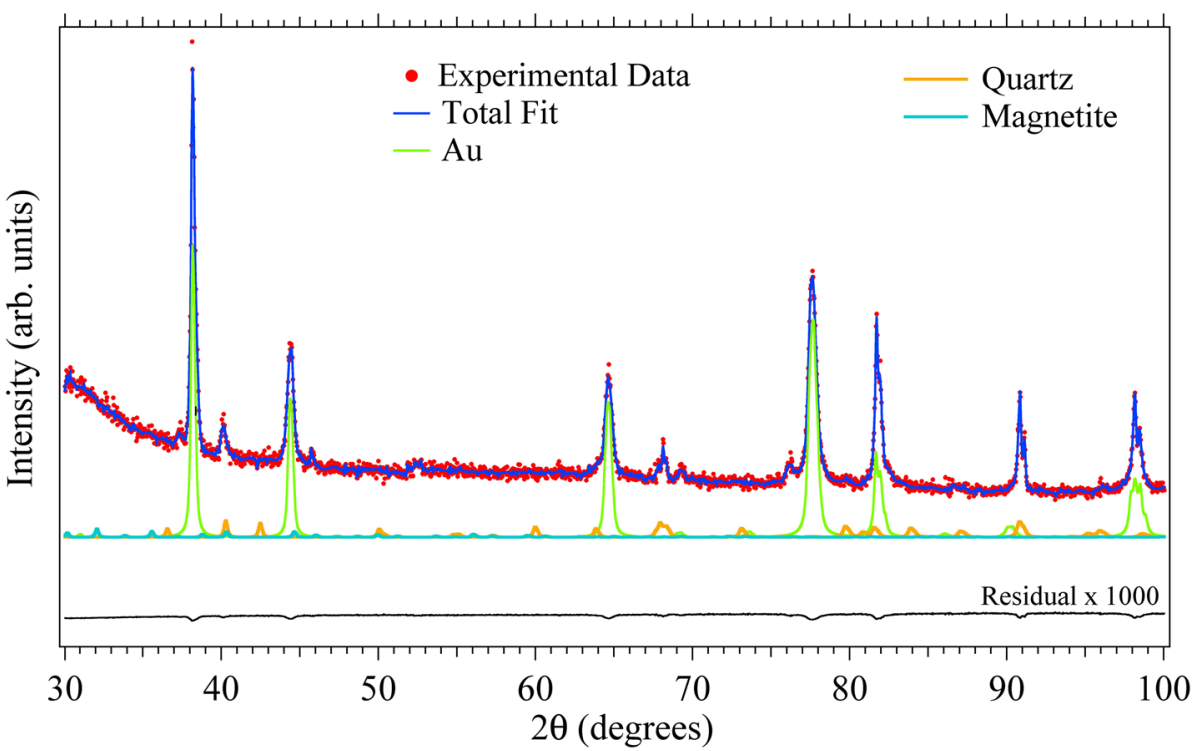

the goniometer. The XRD data were quantitatively analyzed by Rietveld refinement using the MAUD software [26, 27].

\section{Results and discussion}

Figure 4 shows an X-ray diffractogram of the $\mathrm{Au}$ nugget sample in Fig. $2 \mathrm{~b}$ with the result of Rietveld refinement assuming pure $\mathrm{Au}$ together with the residual of the fit [28]. The six pronounced peaks in the diffractogram are indexed as a cubic fcc $\mathrm{Au}$ structure (Fm-3 m space group) with lattice parameter of $a=4.079 \AA$. Table 1ists the full assigned observed peak list as well as the resulting crystallographic parameters from the refinement. These are in agreement with literature assignments for $\mathrm{Au}$ $[28,29]$.

Figure 5 shows an X-ray diffractogram of the impure powder Au sample shown in Fig. 3a. Table 2 lists the refined crystallographic parameters of $\mathrm{Au}$ and the pathfinder minerals identified from powder $\mathrm{Au}$ samples. These data are in agreement with reference data [27-32]. The diffractogram from the unrefined powder sample shows the presence of other minerals, that is, pathfinder minerals for $\mathrm{Au}$. These are dominated by $\mathrm{SiO}_{2}$ (quartz) with some $\mathrm{Fe}_{3} \mathrm{O}_{4}$ (magnetite).

The lattice parameter of the $\mathrm{SiO}_{2}$ in the impure $\mathrm{Au}$ were found to be $a=4.91 \AA$ and $c=5.43 \AA$ (space group P3221), consistent with reference data [30]. This sample also contains $\mathrm{Fe}_{3} \mathrm{O}_{4}$ (cubic, space group
Fd-3 m) with a lattice parameter of $8.36 \AA$, consistent with literature data [27].

Figure 6 shows an X-ray diffractogram from the residual black sand after Au panning. The diffraction peaks of this sample were identified as the crystalline structure of $\mathrm{Fe}_{2} \mathrm{O}_{3}$ (hematite). Table 3 lists the diffraction peaks and crystallographic parameters determined from the Rietveld refinement of $\mathrm{Fe}_{2} \mathrm{O}_{3}$. This is in accordance with literature and reference data $[32,33]$. The crystal structure of $\mathrm{Fe}_{2} \mathrm{O}_{3}$ is rhombohedral with a space group $\mathrm{R}-3 \mathrm{c}$ and lattice constant of $5.0991 \AA[34,35]$.

Comparing Figs. 4 and 5, it can be seen that the latter sample contains $\mathrm{Au}$ together with pathfinder minerals in the form of magnetite and quartz. The most abundant mineral observed in the diffraction pattern of the impure powder $\mathrm{Au}$ sample is $\mathrm{SiO}_{2}$ (quartz) having three distinct peaks at $2 \theta=40.284^{\circ}$, $67.957^{\circ}$ and $90.818^{\circ}$ corresponding to $\{111\},\{212\}$ and $\{312\}$ crystalline planes of the $\mathrm{SiO}_{2}$ phase, respectively. The refined pattern of $\mathrm{SiO}_{2}$ shown in Fig. 5 is in agreement with the literature data in refs [36-39], which also holds true for the moderate amount of magnetite present [27]. This shows that impure Au or final concentrate (non-pure $\mathrm{Au}$ ) have a high quantity (percentage) of pathfinder minerals as impurities. Note that $\mathrm{Au}$ atoms easily substitute with $\mathrm{Ag}$ atoms forming an alloy with the same fcc crystal structure and that it is impossible to distinguish pure $\mathrm{Au}$ from an $\mathrm{Au}-\mathrm{Ag}$ alloy with XRD.

The diffractogram in Fig. 6 contains major peaks at $2 \theta=32.609^{\circ}, 34.915^{\circ}, 38.658^{\circ}, 40.196^{\circ}, 48.618^{\circ}$, 
Table 2 Structural refinement parameters of impure Au powder sample containing other pathfinder minerals

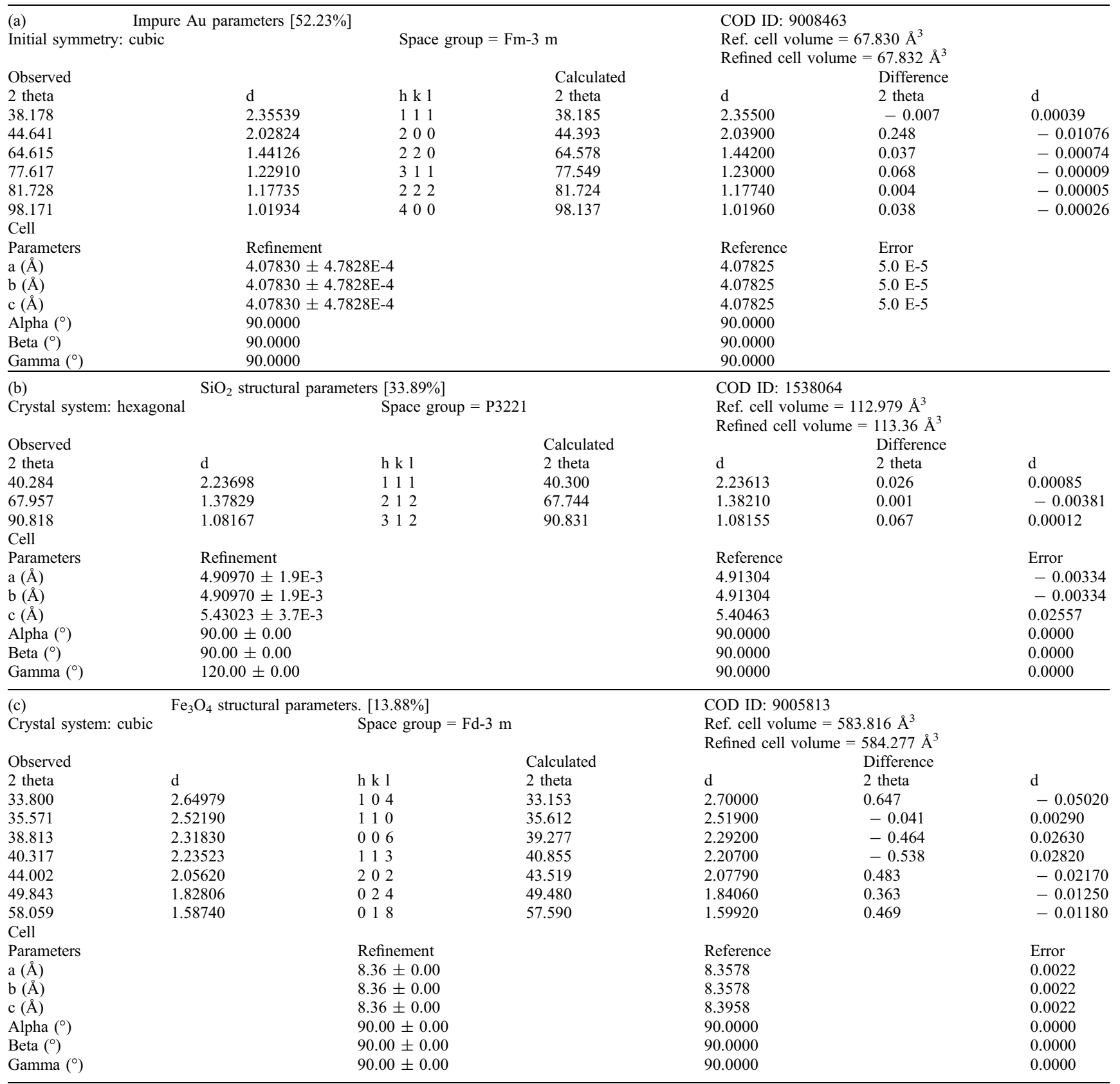

$53.966^{\circ}, 62.990^{\circ}, 69.975^{\circ}, 80.837^{\circ}, 83.475^{\circ}$ and $91.533^{\circ}$ identified as $\{101\},\{110\},\{006\},\{113\},\{024\},\{116\}$, $\{214\},\{208\},\{128\},\{134\}$ and $\{042\}$ crystalline planes of $\mathrm{Fe}_{2} \mathrm{O}_{3}$ (hematite), respectively. These refined peaks are in good agreement with the rhombohedral structure of $\mathrm{Fe}_{2} \mathrm{O}_{3}[32,33]$.
Generally, including possible microstrain in the Rietveld refinement has a negligible effect on the convergence of the fit (residual), indicating that the samples are essentially strain-free. The results from the impure $\mathrm{Au}$ powder sample indicate that $\mathrm{SiO}_{2}$ (quartz) is the dominant impurity mineral serving as the host rock containing all the pathfinder minerals at 
Figure $6 \mathrm{X}$-ray diffractogram of the $\mathrm{Fe}_{2} \mathrm{O}_{3}$ mineral.

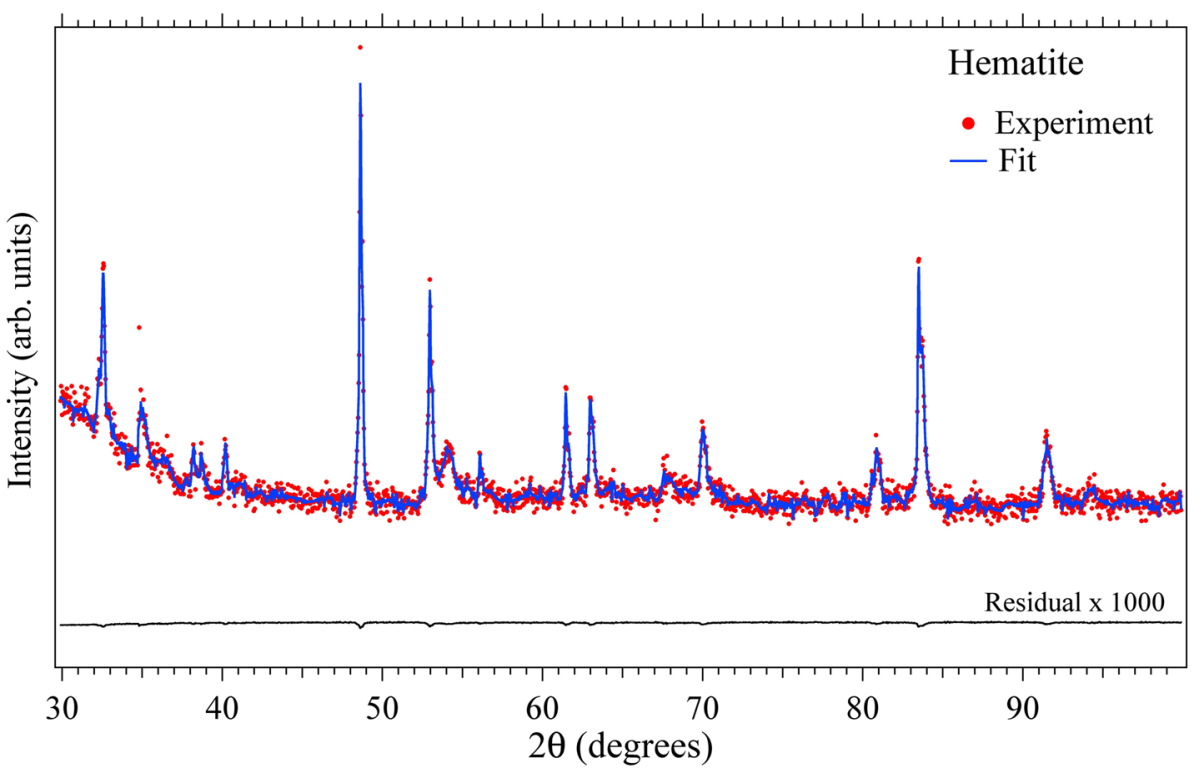

Table 3 Structural refinement parameters of $\mathrm{Fe}_{2} \mathrm{O}_{3}$ powder sample

\begin{tabular}{|c|c|c|c|c|c|c|}
\hline \multicolumn{4}{|c|}{ Crystal system: rhombohedral } & \multicolumn{3}{|c|}{ Space group $=\mathrm{R}-3 \mathrm{c}$} \\
\hline COD ID: 900139 & \multicolumn{3}{|c|}{ Ref. cell volume $=302.722 \AA 3$} & \multicolumn{3}{|c|}{ Refined cell volume $=313.870 \AA 3$} \\
\hline Observed & & & Calculat & & Difference & \\
\hline 2 theta & $\mathrm{d}$ & h k 1 & 2 theta & $\mathrm{d}$ & 2 theta & $\mathrm{d}$ \\
\hline 32.609 & 2.74380 & 101 & 33.158 & 2.70000 & -0.549 & 0.04380 \\
\hline 34.915 & 2.56768 & 110 & 35.612 & 2.51900 & -0.697 & -0.04868 \\
\hline 38.658 & 2.32725 & 006 & 39.277 & 2.29200 & -0.619 & 0.03525 \\
\hline 40.196 & 2.24167 & 113 & 40.855 & 2.20700 & -0.659 & 0.03467 \\
\hline 48.618 & 1.87122 & 024 & 49.480 & 1.84060 & -0.862 & 0.03062 \\
\hline 53.966 & 1.69772 & 116 & 54.091 & 1.69410 & -0.125 & 0.00362 \\
\hline 62.990 & 1.47447 & 214 & 62.451 & 1.48590 & 0.539 & -0.01143 \\
\hline 69.975 & 1.34340 & 208 & 69.601 & 1.34970 & 0.374 & -0.00630 \\
\hline 80.837 & 1.18806 & 128 & 80.711 & 1.18960 & 0.126 & -0.00154 \\
\hline 83.475 & 1.15710 & 134 & 84.916 & 1.14110 & -1.441 & 0.01600 \\
\hline 91.533 & 1.07508 & 042 & 91.345 & 1.07680 & 0.188 & -0.00172 \\
\hline \multicolumn{7}{|l|}{ Cell } \\
\hline \multicolumn{2}{|l|}{ Parameters } & \multicolumn{2}{|c|}{ Refinement } & \multicolumn{2}{|l|}{ Reference } & Error \\
\hline \multicolumn{2}{|l|}{$\mathrm{a}(\AA)$} & \multicolumn{2}{|c|}{$5.0991 \pm 1.4 \mathrm{E}-3$} & \multicolumn{2}{|l|}{5.0380} & 0.0611 \\
\hline \multicolumn{2}{|l|}{ b $(\AA)$} & \multicolumn{2}{|c|}{$5.0991 \pm 1.4 \mathrm{E}-3$} & \multicolumn{2}{|l|}{5.0380} & 0.0611 \\
\hline \multicolumn{2}{|l|}{ c $(\AA)$} & \multicolumn{2}{|c|}{$14.0767 \pm 5.2 \mathrm{E}-3$} & \multicolumn{2}{|l|}{13.7720} & 0.3047 \\
\hline \multicolumn{2}{|l|}{ Alpha $\left(^{\circ}\right)$} & \multicolumn{2}{|c|}{$90.00 \pm 0.00$} & \multicolumn{2}{|l|}{90.0000} & 0.0000 \\
\hline \multicolumn{2}{|l|}{ Beta $\left(^{\circ}\right)$} & \multicolumn{2}{|c|}{$90.00 \pm 0.00$} & \multicolumn{2}{|l|}{90.0000} & 0.0000 \\
\hline \multicolumn{2}{|l|}{ Gamma $\left({ }^{\circ}\right)$} & \multicolumn{2}{|c|}{$90.00 \pm 0.00$} & \multicolumn{2}{|l|}{120.0000} & 0.0000 \\
\hline
\end{tabular}

the mining site. It is known that $\mathrm{SiO}_{2}$ is a so-called gangue mineral (i.e., a commercially nonvaluable mineral that surrounds or is mixed with a valuable mineral) in hydrothermal ore veins [40], to preserve information about the physiochemical situations of the origin of the veins and to understand the formation of mineral deposits. These dominant $\mathrm{SiO}_{2}$ species contain structural defects that favor mineral infusion due to underlying conditions and geological processes, such as crystallization, metamorphism, alterations, changes in crystallization temperatures and precipitation [41-43].

$\mathrm{Au}$ associated with $\mathrm{Fe}_{3} \mathrm{O}_{4}$ is mostly formed in skarns of granular magnetite usually found in contact with metamorphosed areas with magma intrusion into carbonate or silico-carbonate rocks that also 
consist of garnet and silicate minerals, among others. The residual black sand together with other dense minerals is considered to be ore that is left over during $\mathrm{Au}$ refinement and washing at riverbanks when recovering its Au content [44]. This shows that two of the three most common iron ore minerals; $\mathrm{Fe}_{3} \mathrm{O}_{4}$ and $\mathrm{Fe}_{2} \mathrm{O}_{3}$ are widely spread within the mining site and contribute to the $\mathrm{Au}$ host minerals alongside $\mathrm{SiO}_{2}$. In a near-surface environment (oxide area) $\mathrm{Fe}_{2} \mathrm{O}_{3}$ act as the gangue mineral and can be transformed to $\mathrm{Fe}_{3} \mathrm{O}_{4}$ depending on the environmental conditions such as high temperature, oxidation, and $\mathrm{pH}$ [45]. The same color of $\mathrm{Fe}_{2} \mathrm{O}_{3}$ in comparison with black $\mathrm{Fe}_{3} \mathrm{O}_{4}$ makes it difficult to distinguish between the two in branded iron formations and standing water $[44,46]$. It is likely that during the formation of Fe-oxides in the alluvial regime at the Dunkwa-Kubi geological site, $\mathrm{Au}$ is internally captured within structures associated with $\mathrm{Fe}_{2} \mathrm{O}_{3}$ (hematite) that acts as crusts in saprolite and laterite environments. These minerals reveal information about the physiochemical conditions of the origin of structures (structural defects) useful for the understanding of mineral deposit formations.

\section{Conclusions}

This study has revealed that sediments and black sands containing $\mathrm{Au}$ are associated with pathfinding minerals in impure compositions. This is indicative that $\mathrm{Au}$ and pathfinding minerals are all deposited in nature during hydrothermal activation. The XRD analysis identified $\mathrm{Au}, \mathrm{SiO}_{2}$ (quartz), $\mathrm{Fe}_{3} \mathrm{O}_{4}$ (magnetite) and $\mathrm{Fe}_{2} \mathrm{O}_{3}$ (hematite). From the XRD patterns, the impure $\mathrm{Au}$ and $\mathrm{Fe}_{2} \mathrm{O}_{3}$ samples can be attributed to the decomposition and transformation of these indicator minerals. Also, the surface (oxide zones) mineralization is altered by $\mathrm{Fe}_{2} \mathrm{O}_{3}$ as one of the indicator minerals apart from the garnet and the gangue mineral $\mathrm{SiO}_{2}$ to host $\mathrm{Au}$ with other pathfinder minerals beneath the surface.

These results are of importance for the mining industry to underscore the usefulness of XRD in studying soil and sand sediments from mining sites by identifying pathfinder minerals of $\mathrm{Au}$ in potential geological sites.

\section{Acknowledgements}

We acknowledge support from the Swedish Government Strategic Research Area in Materials Science on Functional Materials at Linköping University (Faculty Grant SFO-Mat-LiU No. 2009 00971). M.M. also acknowledges financial support from the Swedish Energy Research (Grant No. 43606-1) and the Carl Tryggers Foundation (CTS20:272, CTS16:303, CTS14:310). Asante Gold Corporation is acknowledged for funding G. K. N.'s industrial $\mathrm{PhD}$ studies at Linköping University, Sweden.

\section{Funding}

Open Access funding provided by Linköping University.

\section{Compliance with ethical standards}

Conflict of interest P. E. and M. M. declare no competing financial interest. G. K. N.'s industry PhD studies are funded by Asante Gold Corporation. Asante Gold Corporation or G.K.N. have no potential financial benefit from this study. The samples in this study are from an artisanal mining site open to the indigenous public.

Open Access This article is licensed under a Creative Commons Attribution 4.0 International License, which permits use, sharing, adaptation, distribution and reproduction in any medium or format, as long as you give appropriate credit to the original author(s) and the source, provide a link to the Creative Commons licence, and indicate if changes were made. The images or other third party material in this article are included in the article's Creative Commons licence, unless indicated otherwise in a credit line to the material. If material is not included in the article's Creative Commons licence and your intended use is not permitted by statutory regulation or exceeds the permitted use, you will need to obtain permission directly from the copyright holder. To view a copy of this licence, visit http://creativecommons.org/licen ses/by $/ 4.0 /$. 


\section{References}

[1] Cook RB, Coogan ER, Neumeier G, Staebler GA (eds) (2003) Gold: The noble mineral. ExtraLapis English no. 5. Lapis International, East Hampton CT

[2] Chapman R, Leake B, Styles M (2002) Microchemical characterization of alluvial gold grains as an exploration tool. Gold Bull 35(2):53-65

[3] Bhargava SK, Garg A, Subasinghe ND (2009) In situ hightemperature phase transformation studies on pyrite, Elsevier. Fuel 88:988-993

[4] Chung FH (1974) Quantitative interpretation of X-ray diffraction patterns of mixtures. I. Matrix-flushing method for quantitative multicomponent analysis. J Appl Crystallogr $7: 519-525$

[5] Bayari EE, Foli G, Gawu SKY (2019) Geochemical and pathfinder elements assessment in some mineralized regolith profiles in Bole-Nangodi gold belt in north-eastern Ghana. Environ Earth Sci 78:268

[6] Rakovan J, Gasbarro N, Nakotte H, Kothapalli K, Vogel SC (2009) Characterization of gold crystallinity by diffraction. Methods Rocks Miner 84:54-61

[7] Naletoa JLC, Perrottaa MM, da Costac FG, de Souza Filhob CR (2019) Point and imaging spectroscopy investigations on the Pedra Branca orogenic gold deposit, Troia Massif, Northeast Brazil: Implications for mineral exploration in amphibolite metamorphic-grade terrains, Elsevier. Ore Geol Rev 107:283-309

[8] Hong H, Tie L (2005) Characteristics of the minerals associated with gold in the shewushan supergene gold deposit, China. Clays Clay Miner 53(2):162-170

[9] Mann AW (1984) Mobility of gold and silver in lateritic weathering profiles: some observations from Western Australia. Econ Geol 79(1):38-49

[10] Nude PM, Asigri JM, Yidana SM, Arhin E, Foli G, Kutu JM (2012) Identifying pathfinder elements for gold in multielement soil geochemical data from the Wa-Lawra Belt Northwest Ghana: a multivariate statistical approach. Int J Geosci 3:62-70

[11] Lindagato P, Li Y, Yang G, Duan F, Wang Z (2018) Application of geostatistical analyst methods in discovering concealed gold and pathfinder elements as geochemical anomalies related to ore mineralization. Geologos 24(2):95-109

[12] Zhao J, Pring A (2019) Mineral transformations in goldsilver tellurides in the presence of fluids: nature and experiment. Minerals 9(3):167

[13] Cairns CJ, McQueen KG, Leah PA (2001) Mineralogical control on element dispersion in regolith over two mineralized shear zones near the Peak, Cobar, New South Wales. J Geochem Explore 72:1-21

[14] Roberts AP, Chang L, Heslop D, Florindo F, Larrasoaña JC (2012) Searching for single domain magnetite in the "pseudo-single-domain" sedimentary haystack: implications of biogenic magnetite preservation for sediment magnetism and relative paleointensity determinations. J Geophys Res 117:B08104

[15] Pati SS, Philip J (2013) Effect of cation trapping on thermal stability of magnetite nanoparticles. J Nanosci Nanotechnol $13: 1-10$

[16] Gilbert B, Katz JE, Denlinger JD, Yin Y, Falcone R, Waychunas GA (2010) Soft X-ray spectroscopy study of the electronic structure of oxidized and partially oxidized magnetite nanoparticles. J Phys Chem C 114:21994-22001

[17] Pati SS, Gopinath S, Panneerselvam G, Antony MP, Philip J (2012) High temperature phase transformation studies in magnetite nanoparticles doped with $\mathrm{CO}_{2}$ ion. J Appl Phys 112:054320

[18] Wang Z, Luan W, Huang J, Jiang C (2011) XRD investigation of microstructure strengthening mechanism of shot peening on laser hardened $17-4 \mathrm{PH}$. Mater Sci Eng A 528:6417-6425

[19] Rosas-Casarez CA, Arredondo-Rea SP, Cruz-Enríquez A, Corral-Higuera R, Gómez-Soberón JM, Medina-Serna TDJ (2018) Influence of size reduction of fly ash particles by grinding on the chemical properties of geopolymers. Appl Sci 8:365

[20] Zhang W, Qian H, Sun Q, Chen Y (2015) Experimental study of the effect of high temperature on primary wave velocity and microstructure of limestone. Environ Earth Sci 74:5739-5748

[21] Zhang Y, Sun Q, Geng J (2017) Microstructural characterization of limestone exposed to heat with XRD SEM and TGDSC. Mater Charact 134:285-295

[22] Kesse GO (1984) The occurrence of gold in Ghana. In: Foster RP (ed) Gold '82: the geology, geochemistry and genesis of gold deposits. Geological Society of Zimbabwe, pp 648-650

[23] Kim BJ, Cho KH, Lee SG, Park C-Y, Choi NC, Lee S (2018) Effective gold recovery from near-surface oxide zone using reductive microwave roasting and magnetic separation. Metals 8:957. https://doi.org/10.3390/met8110957

[24] https://commons.wikimedia.org/wiki/Category:Maps_of_Gh ana\#/media/File:Un-ghana.png

[25] https://rsc.aux.eng.ufl.edu/_files/documents/2714.pdf/

[26] Wechsler BA, Lindsley DH, Prewitt CT (1984) Crystal structure and cation distribution in titanomagnetites (Fe3xTixo4). Am Mineral 69:754 
[27] Finger LW, Hazen RM, Hofmeister AM (1986) High-pressure crystal chemistry of spinel $(\mathrm{MgAl} 2 \mathrm{O} 4)$ and magnetite $\left(\mathrm{Fe}_{3} \mathrm{O}_{4}\right)$ : comparisons with silicate spinels Sample: $\mathrm{P}=13$ kbar. Phys Chem Miner 13:215-220

[28] Swanson HE, Tatge E (1953) Standard X-ray diffraction powder patterns. Natl. Bur. Stand. (U.S.), Circ. 539, U.S. Govt. Print. Off. Washington, D.C., vol I, p 23 and 33

[29] Wyckoff RWG (1963) Cubic closest packed, ccp, structure database. In: Crystal structures, 2nd edn, vol 1. Interscience Publishers, Wiley, New York, London, Sydney, pp 7-83

[30] Kern A, Eysel W (1993) Mneralogisch-Petrograph ICDD Grant-in-Aid. Inst Univ, Heodelberg, Germany

[31] Hanic F, Sumichrast L (1974) Alpha-beta phase transition in quartz. Silikaty 18:1-9

[32] Morris MC et al (1981) Standard X-ray diffraction powder patterns. Nat. Bur. Stand. (U.S.), Monogr. 25 - Sec. 18, p 37, CODEN:NBSMA6, Iron oxide (hematite), a- $\mathrm{Fe}_{2} \mathrm{O}_{3}$

[33] Blake RL, Hessevick RE, Zoltai T, Finger LW (1966) Refinement of the hematite structure. Am Miner 51:123-129

[34] Lutterotti L (2010) Total pattern fitting for the combined size-strain-stress-texture determination in thin film diffraction. Nuclear Inst Methods Phys Res B 268:334-340

[35] Lutterotti L, Bortolotti M, Ischia G, Lonardelli I, Wenk H-R (2007) Rietveld texture analysis from diffraction images. Z Kristallogr Suppl 26:125-130

[36] Kihara K (1990) An X-ray study of the temperature dependence of the quartz structure. Eur J Mineral 2:63-77

[37] Trostel LJ, Wynne DJ (1940) Determination of quartz (free silica) in refractory clays. J Am Ceram Soc 23:18-22

[38] Calvert SE (1966) Accumulation of diatomaceous silica in the sediments of the Gulf of California. Geol Soc Am Bull 77:569-596

[39] Adams FV, Peter A, Joseph IV, Sylvester OP, Mulaba-Bafubiandi AF (2019) Purification of crude oil contaminated water using fly ash/clay Elsevier. J Water Process Eng 30:100471

[40] Götze J (2009) Chemistry, textures and physical properties of quartz-Geological interpretation and technical application. Mineral Mag 73:645-671

[41] Rusk B (2014) Quartz cathodoluminescence: textures, trace elements, and geological applications. In: Coulson IM (ed) Cathodoluminescence and its application to geoscience. Mineralogical Association of Canada, Québec City, QC, Canada, pp 127-141

[42] Götte T, Ramseyer K (2012) Trace element characteristics, luminescence properties and real structure of quartz. In: Götze J, Möckel R (eds) Quartz: deposits, mineralogy and analytics. Springer, Berlin/Heidelberg, Germany, pp 256-285

[43] Weil JA (1993) A review of the EPR spectroscopy of the point defects in a-quartz: the decade 1982-1992. In: Deal BE, Helms CR (eds) Physics and chemistry of $\mathrm{SiO} 2$ and the $\mathrm{Si}-\mathrm{SiO} 2$ interface 2. Plenum Press, New York, NY, USA, pp 131-144

[44] Yuan K, Lee SS, Cha W, Ulvestad A, Kim H, Abdilla B, Sturchio NC, Fenter P (2019) Oxidation induced strain and defects in magnetite crystals. Nat Commun 10:703

[45] Knudsen M, Madsen MB, Kakane V, Awadzi T, Hviid SF, Breuning-Madsen H (2000) Comparison of magnetic particles in airborne dust on Mars and Harmattan dust from south of Sahara, geografisk Tidsskrift. Dan J Geogr 100:1-6

[46] Cornell RM, Schwertmann U (1996) The iron oxides. Wiley, Germany, pp 4-26

Publisher's Note Springer Nature remains neutral with regard to jurisdictional claims in published maps and institutional affiliations. 